\title{
KERAGAMAN AKTIVITAS INSEKTISIDA CALOPHYLLUM SOULATTRI BURM. F. (CLUSIACEAE) DARI KALIMANTAN BARAT
}

\author{
Edy Syahputra ${ }^{1}$, Djoko Prijono ${ }^{2}$, Fadjar Rianto ${ }^{1}$
}

\begin{abstract}
Diversity of insecticide activity of Calophylum soulattri Burm. F. (Clusiaceae) originate from West Kalimantan. The objective of this research was to evaluate the insecticidal activity of the bark extract of Calophyllum soulattri from West Borneo against Crocidolomia pavonana (F.) (Lepidoptera: Pyralidae) larvae. Extraction of the bark was performed with maceration method using ethanol and continued by acetone reextraction. High performance liquid chromatography (HPLC) with $\mathrm{C}_{18}$ column (reversed-phase) and methanol-water (1:1) as the mobile phase was used to measure the amount of active components. Bioassays were done using leaf-residual method. The results showed that acetone bark extract of 10 sample plants of $C$. soulattri possessed strong lethal effect against $C$. pavonana larvae. The lethal effect of the extracts did not differ from each other and the correlation with the content of active components was not significant. The sample plant no. 12 showed the highest yield of acetone extract. Based on both the insecticidal activity and its rendement, it is concluded that the sample plant no. 12 is promising to be used as a parent plant for mass-propagation of source plants
\end{abstract}

Key words: Calophyllum soulattri, botanical insecticide, bioactivity variation.

\section{PENDAHULUAN}

Hingga kini, di Indonesia masih banyak petani yang tetap mengandalkan pengendalian kimia menggunakan insektisida sintetik dalam mengelola hama di lahan pertaniannya. Kenyataan tersebut, selain dapat langsung dilihat di lapangan, juga tercermin dari meningkatnya jumlah bahan aktif pestisida yang terdaftar pada Komisi Pestisida setiap tahunnya. Bahan aktif tersebut umumnya berasal dari luar negeri sehingga biaya impornya ke Indonesia sangat mahal.

Penggunaan insektisida sintetik selain memiliki keunggulan juga memiliki kelemahan. Dampak negatif yang dirasakan akibat pemakaian insektisida sintetik di antaranya pencemaran lingkungan, resurjensi dan resistensi hama, serta kematian hewan bukan sasaran (Kishi et al., 1995). Dalam menghadapi berbagai kendala tersebut, pemerintah telah mengambil langkah-langkah berupa kepedulian lingkungan. Peraturan perundangan seperti Inpres No. 3/1986 dan PP No 6/1995 secara tersirat mengharapkan agar pengembangan sumber daya, pelestarian lingkungan dan kesehatan manusia dapat dijadikan prioritas dasar pembangunan pertanian. Salah satu alternatif yang dapat dikerjakan dalam pembangunan pertanian yang terkait dengan perlindungan tanaman ialah pemanfaatan senyawa aktif asal tumbuhan sebagai insektisida botani.

Dari segi ekologi, insektisida botani memiliki kelebihan tertentu dibandingkan dengan insektisida sintetik. Insektisida botani memiliki sifat tidak stabil sehingga mudah terurai di alam (Isman, 1995). Beberapa jenis insektisida botani dilaporkan memiliki toksisitas yang rendah terhadap organisme bukan sasaran (Schmutterer, 1997). Di sisi lain harga insektisida sintetik juga cukup mahal dan jauh dari jangkauan ekonomi kebanyakan petani. Persediaan pestisida sintetik juga terbatas pada daerah tertentu sehingga petani sulit untuk memperolehnya. Permasalahan-permasalahan di atas mendorong orang untuk mencari dan memanfaatkan bahan tumbuhan lokal yang berkhasiat sebagai insektisida.

Hutan Kalimantan Barat merupakan hutan tropis basah yang diperkirakan menyimpan jenis-jenis tumbuhan yang memiliki aktivitas terhadap serangga. Ketersediaan tumbuhan sebagai sumber bahan insektisida di hutan tropis tampaknya lebih menjanjikan. Di antara jenis tumbuhan asal Kalimantan Barat yang sedang diteliti aktivitas insektisidanya saat ini adalah Calophyllum soulattri (Clusiaceae). Syahputra et al. (2001) melaporkan bahwa ekstrak kulit batang $C$. soulattri memiliki aktivitas insektisida yang kuat terhadap larva Crocidolomia pavonana (F.) (Lepidoptera: Pyralidae). Sediaan kulit batang $C$. soulattri yang diekstrak dengan campuran air-aseton-metanol (18:1:1) memiliki aktivitas insektisida terhadap larva C. pavonana dengan $\mathrm{LC}_{50}$ 4,29\%. Pada penelitian lain, Syahputra et al. (2004a) melaporkan bahwa ekstrak metanol kulit batang C. soulattri memiliki aktivitas insektisida yang kuat terhadap larva

\footnotetext{
${ }^{1}$ Dosen Fakultas Pertanian, Universitas Tanjungpura, Pontianak.

${ }^{2}$ Dosen Departemen Proteksi Tanaman, Fakultas Pertanian, Institut Pertanian Bogor, Jl. Kamper Kampus IPB Darmaga, Bogor
} 
C. pavonana dengan $\mathrm{LC}_{50}$ 0,15\%. Selain kulit batang, getah kulit batang tumbuhan tersebut juga lebih aktif terhadap larva C. pavonana dengan $\mathrm{LC}_{50}$ 0,04\% (Syahputra et al. 2004b).

Selama ini, pencarian tumbuhan $C$. soulattri unggul sebagai tanaman induk belum pernah dilakukan. Dalam usaha pengembangan dan pemberdayaan tumbuhan lokal sebagai agens pengendali hama, perlu dilakukan pencarian tumbuhan unggul. Tumbuhan unggul dimaksud ialah tumbuhan yang memiliki kandungan senyawa aktif dan aktivitas insektisida yang tinggi sehingga dapat dijadikan sebagai tanaman induk untuk pengembangan tanaman tersebut sebagai sumber insektisida botani. Penelitian ini bertujuan untuk mencari tumbuhan induk C. soulattri melalui evaluasi keragaman aktivitas insektisida sediaan dari 10 nomor tumbuhan.

\section{METODE PENELITI AN}

Penelitian dilaksanakan di Laboratorium Hama dan Penyakit Tumbuhan, Jurusan Agronomi, Fakultas Pertanian, Universitas Tanjungpura, dan Laboratorium Fisiologi dan Toksikologi Serangga (Fistok), Departemen Proteksi Tanaman, Fakultas Pertanian, Institut Pertanian Bogor (IPB), selama tahun 2005.

Tumbuhan Sumber Senyawa Aktif. Bahan tumbuhan uji yang digunakan ialah kulit batang Calophyllum soulattri, yang diambil dari 10 nomor tumbuhan yang tumbuh di berbagai lokasi secara acak di sepanjang Sungai Matan, Kecamatan Teluk Melano, Kabupaten Ketapang, Provinsi Kalimantan Barat.

Serangga Uji . Serangga uji Crocidolomia pavonana diperbanyak di Laboratorium Fistok, Departemen Proteksi Tanaman, Fakultas Pertanian, IPB. Serangga dipelihara menurut cara seperti yang diuraikan oleh Prijono (1998). Serangga uji yang digunakan dalam pengujian ialah larva instar II.

Ekstraksi Komponen Aktif. Ekstraksi dilakukan menurut cara yang digunakan oleh Syahputra (2005). Kulit batang C. soulattri dikeringudarakan, diblender hingga menjadi serbuk dan diayak menggunakan pengayak kasa berjalinan $1 \mathrm{~mm}$. Serbuk ayakan ditimbang untuk keperluan ekstraksi. Kadar air bahan yang diekstrak dihitung berdasarkan bobot kering dengan rumus $\mathrm{H}=(\mathrm{BE} /(\mathrm{BS} \times \mathrm{PBK})) \times 100 \% ; \mathrm{H}$ : hasil ekstrak (\%), BE: bobot ekstrak, BS: bobot segar bahan yang diekstrak, PBK: proporsi bobot kering bahan yang diekstrak.

Serbuk hasil ayakan kulit batang yang telah ditimbang diekstrak dengan metode maserasi. Sebagai pelarut digunakan etanol dengan perbandingan bobot bahan dan pelarut 1:10 (w/v). Bahan direndam dalam etanol selama 3 x 24 jam, selanjutnya disaring menggunakan corong yang dialasi kertas saring. Hasil penyaringan diuapkan di dalam laminar air flow dengan bantuan kipas angin. Ekstrak etanol kulit batang $C$. soulattri yang diperoleh diekstraksi kembali dengan pelarut aseton dengan perbandingan bobot bahan dan pelarut 1:10 (w/v). Ekstrak aseton yang diperoleh selanjutnya diuapkan pelarutnya dengan rotary evaporator pada suhu 55-60 ${ }^{\circ} \mathrm{C}$ dan penghampaan pada tekanan $580-600 \mathrm{mmHg}$ sehingga diperoleh ekstrak aseton. Ekstrak-ekstrak yang diperoleh disimpan dalam lemari es $\left(\leq 4{ }^{\circ} \mathrm{C}\right)$ hingga saat digunakan untuk pengukuran kandungan komponen aktif dan pengujian aktivitas insektisida.

Pengukuran Kandungan Komponen Aktif. Pengukuran senyawa aktif utama dilakukan dengan membandingkan kandungan komponen aktif yang terkandung dalam ekstrak aseton dengan konsentrasi komponen aktif standar. Sebagai standar komponen aktif digunakan fraksi 1.1 (Gambar 1) yang diperoleh dari hasil pemurnian kulit batang $C$. soulattri yang dilakukan penulis pada penelitian sebelumnya (Syahputra, 2005). Konsentrasi larutan standar yang digunakan untuk pengukuran kandungan komponen aktif adalah $1 \mathrm{mg} / \mathrm{ml}$, sedangkan konsentrasi larutan sampel sebesar $0,05 \%$ dengan pelarut campuran aseton metanol 3:1. Pengukuran menggunakan alat high performance liquid chromatography (HPLC) dengan kondisi kolom $\mathrm{C}_{18}$ (reversed-phase) dan laju aliran $1 \mathrm{ml} /$ menit (Range 0,1 AVFS). Fase mobil yang digunakan adalah metanol-air (1:1). Deteksi senyawa dilakukan dengan detektor UV pada panjang gelombang 331. Pada panjang gelombang ini terdeteksi serapan maksimum dari komponen fraksi (Syahputra, 2005).

Pengujian Aktivitas Insektisida. Pengujian aktivitas insektisida dilakukan dengan metode residu pada daun (Syahputra et al. 2004a). Setiap sediaan diuji pada lima taraf konsentrasi (masing-masing dengan tiga ulangan, 15 larva/ulangan). Konsentrasi yang digunakan untuk pengujian ditentukan melalui uji 


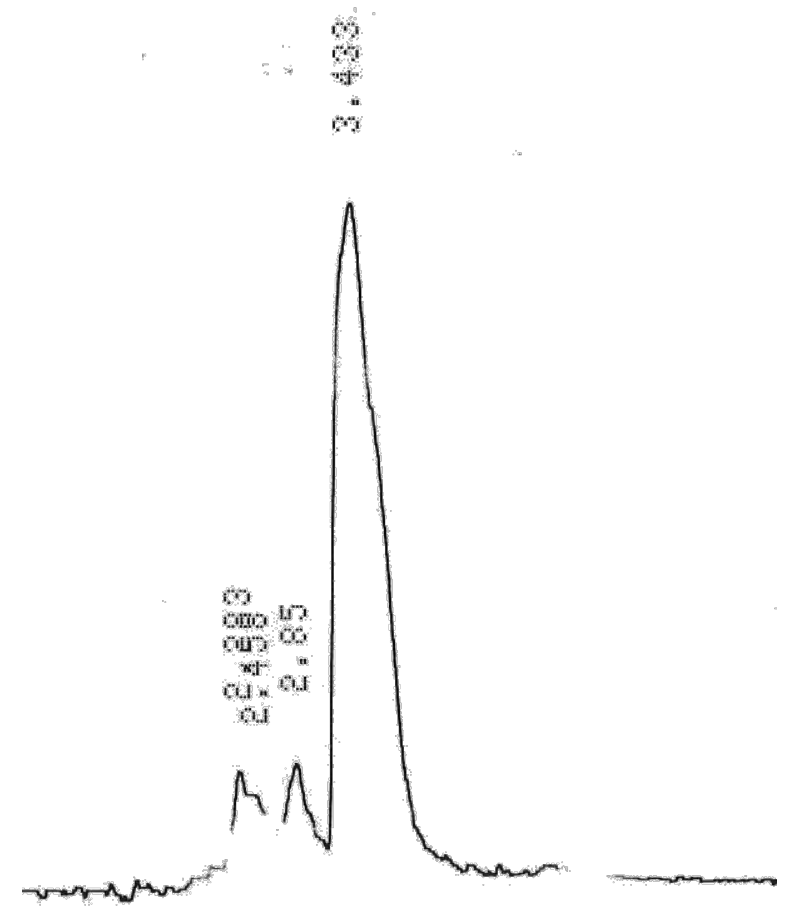

Gambar 1. Waktu retensi (menit) puncak komponen aktif pada pengukuran standar (fraksi 1.1 kulit batang tumbuhan C. soulattri)

pendahuluan. Untuk memperoleh larutan dengan konsentrasi yang diinginkan, ekstrak aseton dilarutkan dengan campuran aseton metanol (3:1). Sebanyak $50 \mu$ l sediaan konsentrasi tertentu dioleskan merata pada setiap permukaan cakram daun brokoli (diameter $3 \mathrm{~cm}$ ) menggunakan sonde mikro (microsyringe). Setelah pelarut menguap, dua potong daun perlakuan diletakkan dalam cawan petri (diameter $9 \mathrm{~cm}$ ) yang dialasi tisu. Selanjutnya ke dalam setiap cawan petri dimasukkan 15 ekor larva instar II C. pavonana. Larva kontrol diberi pakan daun yang diolesi pelarut saja. Pemberian pakan daun perlakuan dilakukan selama 48 jam, selanjutnya larva diberi pakan daun tanpa perlakuan hingga mencapai instar IV. Jumlah larva yang mati dicatat. Penentuan nilai LC $_{50}$ (lethal concentration) dilakukan dengan analisis probit menggunakan program komputer SAS (SAS Institute, 1990). Hubungan antara kandungan senyawa aktif utama dan $\mathrm{LC}_{50}$ ekstrak aseton $C$. soulattri diolah dengan analisis korelasi (Steel \& Torrie, 1993).

\section{HASIL DAN PEMBAHASAN}

Kandungan Komponen Aktif. Hasil pengukuran kandungan komponen aktif ekstrak aseton kulit batang tumbuhan Calophyllum soulattri yang terdeteksi menunjukkan kecilnya variasi kandungan komponen aktif (Tabel 1). Kandungan komponen aktif 10 nomor C. soulattri yang dipelajari lebih besar dari $95 \%$ dengan kisaran 95,2\% - 98,3\%. Kromatogram hasil pengukuran komponen aktif ekstrak aseton kulit batang $C$. soulattri setiap nomor tumbuhan disajikan pada Gambar 2-4. Kandungan komponen aktif tertinggi terdapat pada tumbuhan sampel nomor 12 (98,3\%), sedangkan yang terendah terdapat pada sampel nomor 2 (95,2\%). Keragaman kandungan komponen aktif ini tampaknya belum mampu menyebabkan perbedaan aktivitas insektisida ekstrak yang diuji (Tabel 2). Hal ini disebabkan karena perbedaan kandungan senyawa aktif di antara 
Tabel 1. Persentase komponen aktif dalam ekstrak aseton kulit batang C. soulattri yang terdeteksi pada waktu retensi yang dianggap sama

\begin{tabular}{ccc}
\hline Nomor tumbuhan & Waktu retensi & $\begin{array}{c}\text { Kandungan komponen aktif } \\
\text { terdeteksi (\%) }\end{array}$ \\
\hline Standar & 3,433 & - \\
2 & 3,427 & 95,2 \\
3 & 3,390 & 97,7 \\
6 & 3,480 & 97,3 \\
7 & 3,480 & 98 \\
10 & 3,450 & 97,7 \\
11 & 3,450 & 98,2 \\
12 & 3,432 & 98,3 \\
15 & 3,417 & 98,3 \\
26 & 3,400 & 98,2 \\
27 & 3,395 & 98,1
\end{tabular}

${ }^{1}$ Deteksi pada panjang gelombang $331 \mathrm{~nm}$, konsentrasi sampel yang dinjeksi 0,05\%

Tabel 2. Parameter hubungan konsentrasi-mortalitas ekstrak aseton kulit batang C. soulattri terhadap larva C. pavonana $^{1}$

\begin{tabular}{ccc}
\hline Nomor tumbuhan & \multicolumn{2}{c}{$\mathrm{LC}_{50}(\mathrm{SK} 95 \%)(\%)$} \\
\hline 2 & 0,05 & $(0,04-0,05)$ \\
3 & 0,04 & $(0,04-0,05)$ \\
6 & $0,04 \quad(0,04-0,05)$ \\
7 & $0,05(0,04-0,06)$ \\
11 & $0,04 \quad(0,04-0,05)$ \\
12 & $0,04 \quad(0,04-0,05)$ \\
15 & $0,04 \quad(0,04-0,05)$ \\
26 & $0,04 \quad(0,03-0,05)$ \\
27 & $0,04 \quad(0,04-0,05)$ \\
\hline
\end{tabular}

${ }^{1}$ Jumlah larva instar II yang diberi perlakuan 225 ekor dan kontrol 45 ekor 

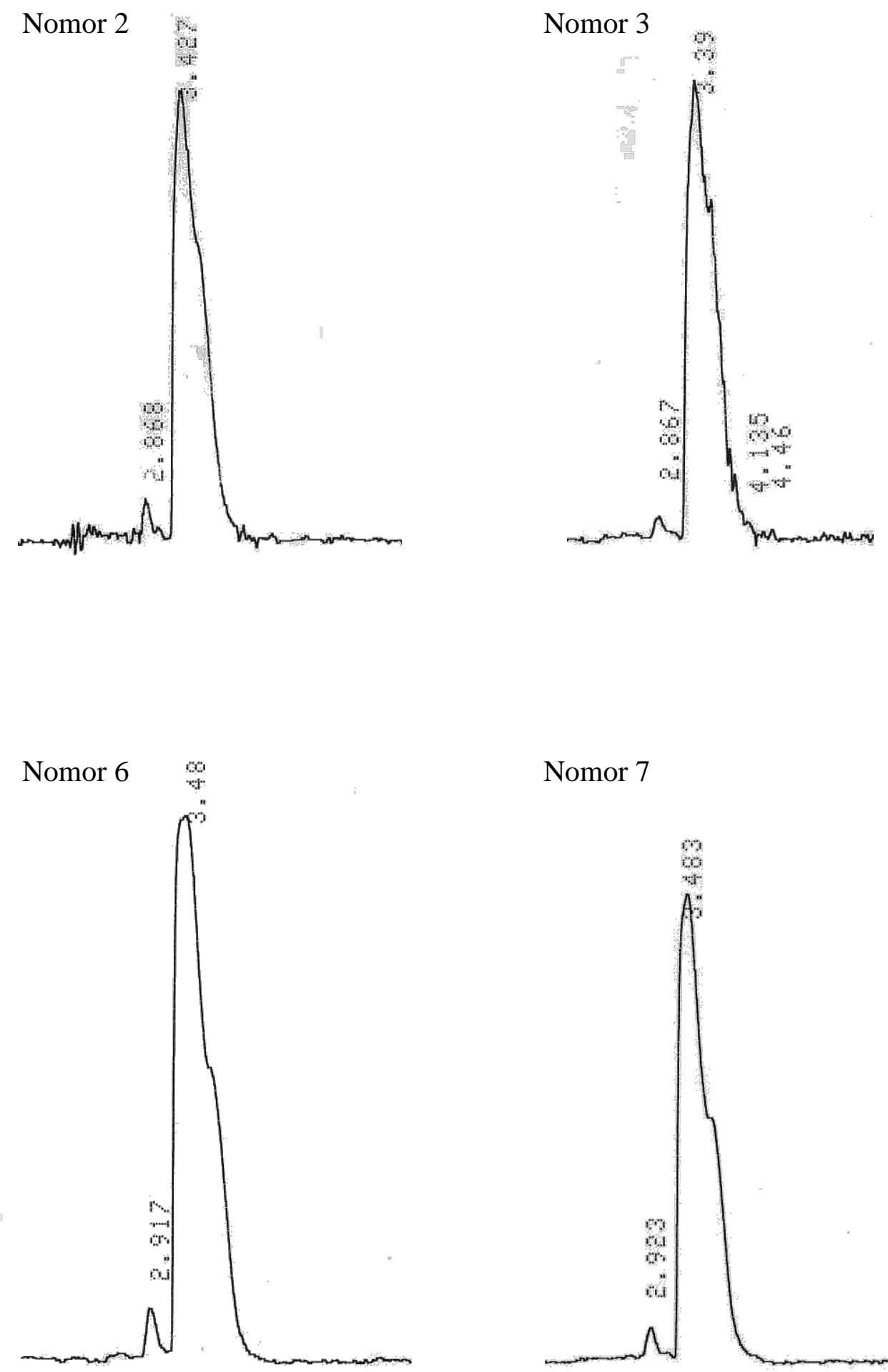

Nomor 7

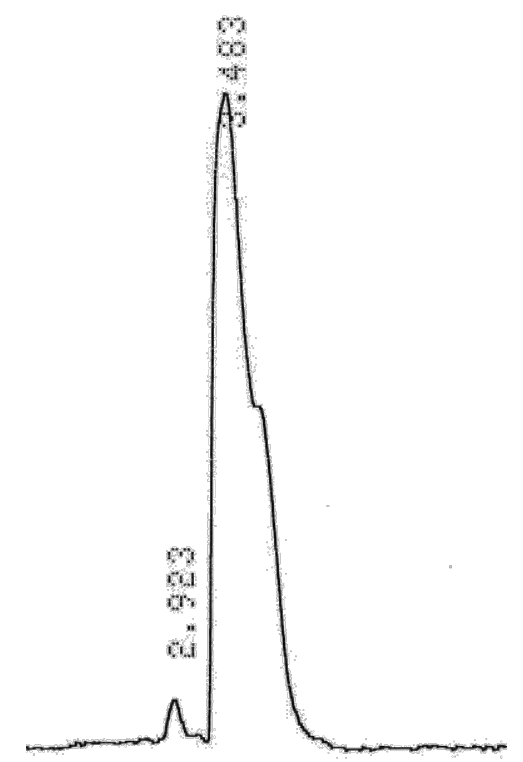

Gambar 2. Waktu retensi (menit) puncak komponen aktif ekstrak aseton kulit batang tumbuhan C. soulattri nomor sampel 2, 3, 6, dan 7 

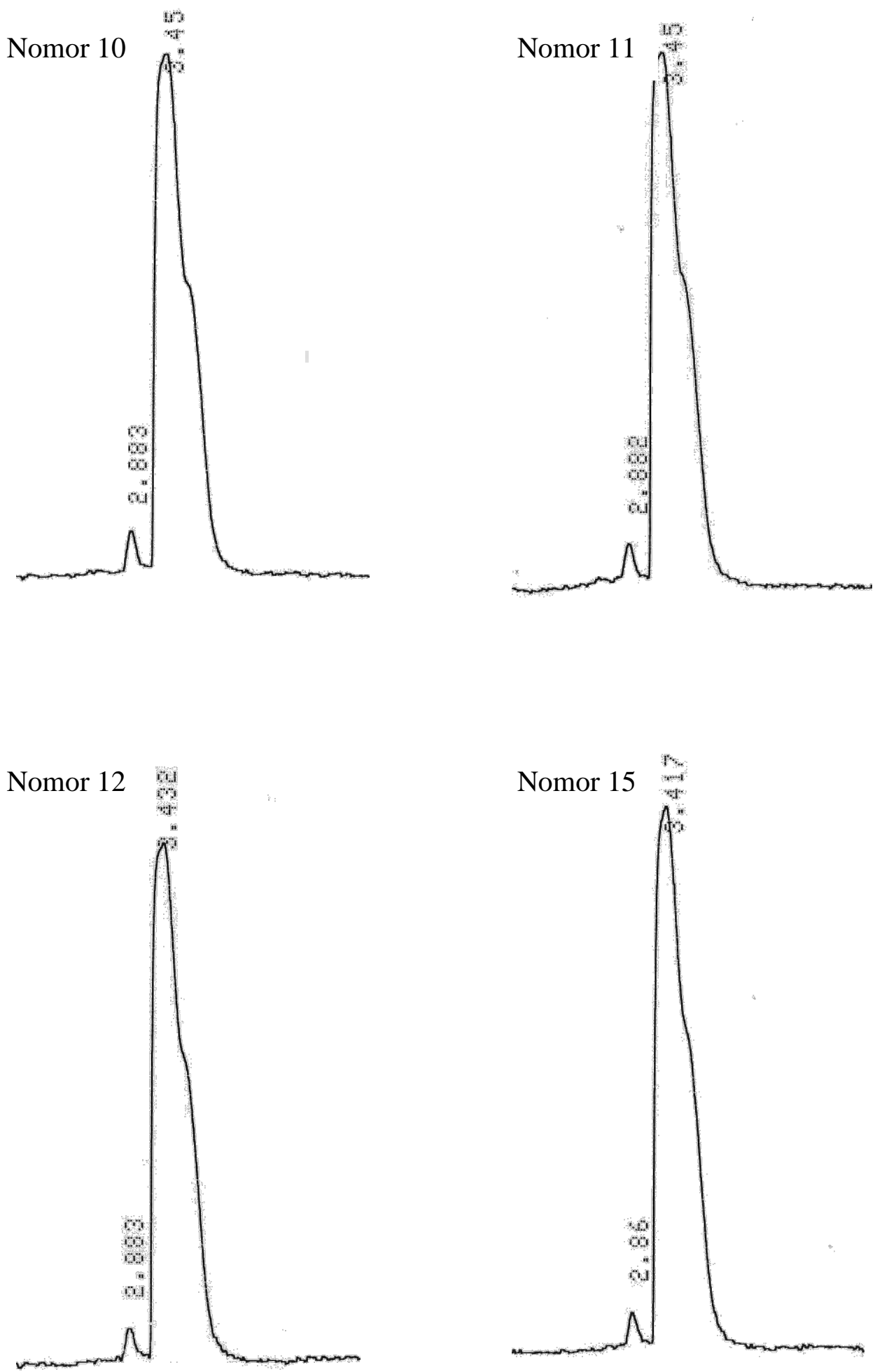

Gambar 3. Waktu retensi (menit) puncak komponen aktif ekstrak aseton kulit batang tumbuhan C. soulattri nomor sampel 10, 11, 12, dan 15 

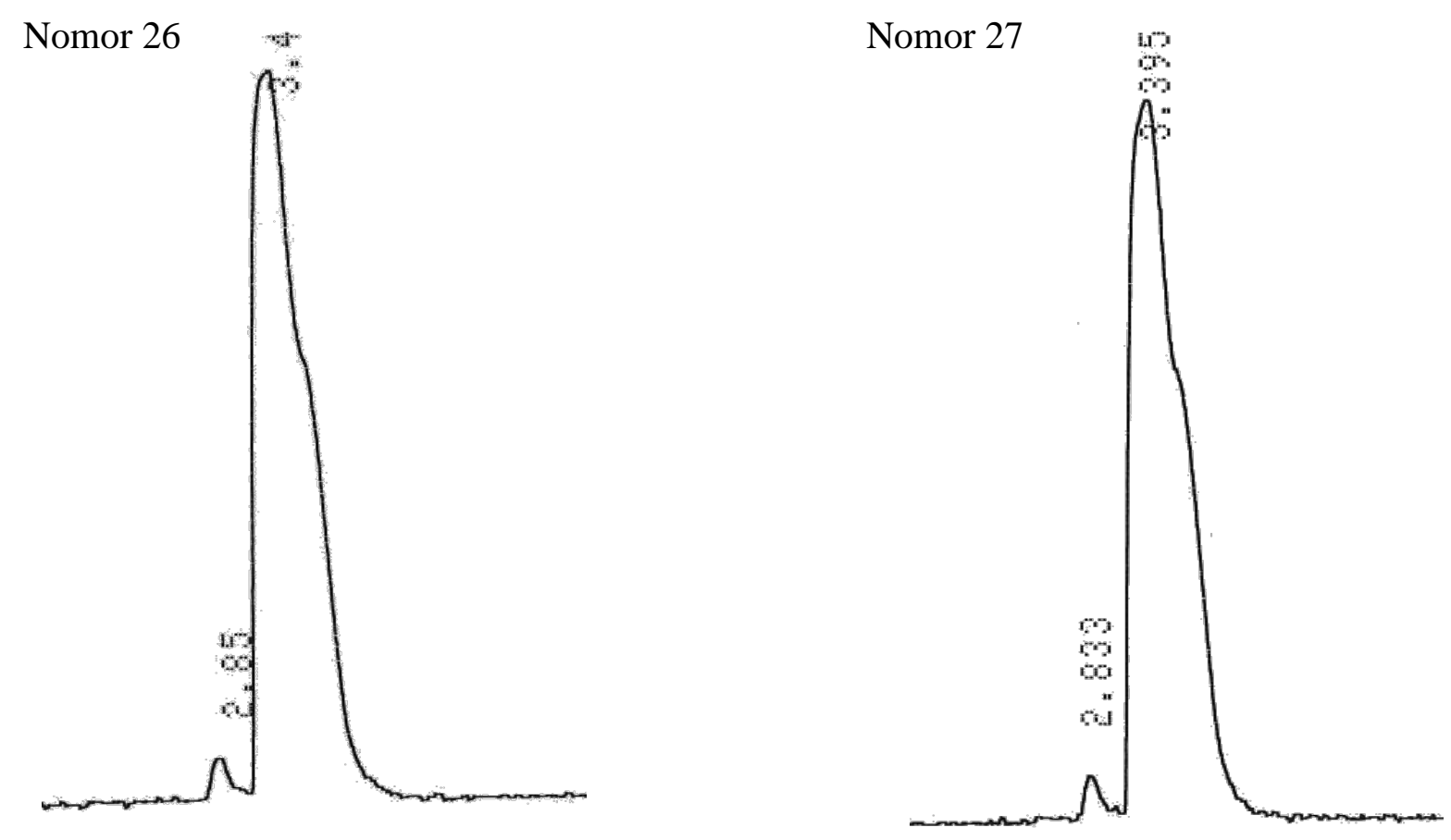

Gambar 4. Waktu retensi (menit) puncak komponen aktif ekstrak aseton kulit batang tumbuhan C. soulattri nomor sampel 26 dan 27

tumbuhan sampel tidak mencolok. Tidak tingginya perbedaan kandungan komponen aktif tersebut dikarenakan lokasi tumbuh tumbuhan sampel yang dipelajari tampaknya relatif sama sehingga cekaman lingkungan dari tumbuhan-tumbuhan sampel tersebut tidak terlalu berbeda. Cekaman lingkungan dapat mempengaruhi sintesis metabolit-metabolit sekunder di dalam tumbuhan sampel tersebut yang di antaranya dapat berfungsi sebagai senyawa aktif insektisida. Hal berbeda sebelumnya dilaporkan bahwa ekstrak kulit batang C. soulattri yang berasal dari provinsi yang berbeda memiliki aktivitas yang berbeda. Aktivitas insektisida ekstrak kulit batang C. soulattri asal Kalimantan Barat menunjukkan aktivitas insektisida yang lebih tinggi dibandingkan dengan ekstrak kulit batang C. soulattri asal Jawa Barat dan Riau (Syahputra et al., 2004a).

Aktivitas Insektisida. Hasil pengujian aktivitas insektisida kulit batang $C$. soulattri menunjukkan bahwa semua tumbuhan sampel yang diuji memiliki aktivitas insektisida yang kuat dengan toksisitas yang tidak berbeda nyata (Tabel 2). Selang kepercayaan 95\% dari LC $_{50}$ ekstrak semua tumbuhan sampel saling tumpang tindih. Nilai $\mathrm{LC}_{50}$ semua tumbuhan sampel berada pada kisaran 0,04\% - 0,05\%. Selain aktivitas insektisida, sediaan tumbuhan $C$. soulattri juga memiliki bioaktivitas lainnya seperti aktivitas penghambat makan dan penghambat pertumbuhan larva C. pavonana (Syahputra et al., 2006).

Untuk penggunaan bahan tanaman langsung di lapangan selain toksisitas yang tinggi, rendemen ekstrak merupakan faktor penting yang perlu diperhatikan. Rendemen ekstrak aseton kulit batang tumbuhan sampel yang diukur bervariasi (Tabel 3). Kandungan rendemen ekstrak aseton tertinggi terdapat pada tumbuhan sampel nomor 12 yakni sebesar $28,5 \%$, sedangkan terendah terdapat pada tumbuhan sampel nomor 10 dan 26 yakni sama-sama sebesar 15,3\%. Variasi rendemen ini tampaknya berhubungan dengan keliling batang tumbuhan. Secara visual tampak bahwa keliling batang tumbuhan sampel yang besar memiliki ketebalan kulit batang yang tebal. Untuk menentukan keeratan hubungan peubah 
Tabel 3. Keliling batang tumbuhan Calophyllum soulattri dan rendemen ekstrak asetonnya

\begin{tabular}{ccc}
\hline Nomor tumbuhan & Keliling batang $(\mathrm{cm})$ & Rendemen ekstrak aseton (\%) \\
\hline 2 & 96 & 16,9 \\
3 & 150 & 27,8 \\
6 & 145 & 26,2 \\
7 & 119 & 19,9 \\
10 & 80 & 15,3 \\
11 & 81 & 16,9 \\
12 & 170 & 28,5 \\
15 & 115 & 21,0 \\
26 & 94 & 15,3 \\
27 & 95 & 18,7 \\
\hline
\end{tabular}

tersebut diperlukan penelitian tersendiri di luar penelitian ini.

Sehubungan dengan tidak berbedanya aktivitas insektisida dari semua nomor tumbuhan yang diuji, maka untuk menentukan tumbuhan unggul yang merupakan tujuan penelitian ini dilihat dari rendemennya. Dengan demikian, tumbuhan sampel 12 lebih baik dijadikan sebagai tanaman induk dibandingkan dengan tumbuhan sampel nomor lainnya.

Tidak nyatanya toksisitas insektisida ekstrak aseton ini disebabkan oleh kecilnya keragaman kandungan komponen aktif (Tabel 1). Hasil analisis korelasi hubungan antara kandungan senyawa aktif sebagai peubah bebas dengan $\mathrm{LC}_{50}$ sebagai peubah terikat menunjukkan bahwa kedua peubah memiliki hubungan linier yang tidak nyata (b \pm standar eror melewati nol).

\section{SIMPULAN DAN SARAN}

Dengan memperhatikan aktivitas insektisida dan rendeman ekstrak aseton kulit batang $C$. soulattri disimpulkan bahwa tumbuhan sampel nomor 12 dapat dijadikan sebagai tanaman induk untuk perbanyakan C. soulattri sebagai sumber insektisida botani.

\section{SANWACANA}

Tim penulis mengucapkan terima kasih kepada Direktorat Binlitabmas Ditjen Dikti yang telah memberikan dana penelitian dengan nomor kontrak 042/SPPP/PP/DP3M/IV/2005.

\section{DAFTAR PUSTAKA}

Isman, M.B. 1995. Leads and prospects for development of new botanical insecticides. Rev. Pestic. Toxicol. 3: 1-20.

Kishi, M., N. Hirschhorn, M. Djajadisastra, L.N. Satterlee, S. Strowman \& R. Dilt. 1995. Relationship of pesticide spraying to signs and symptoms in Indonesian farmers. Scand. J. Work Environ. Health 21:124-133.

Prijono, D. 1998. Insecticidal activity of meliaceous seed extracts against Crocidolomia binotalis Zeller (Lepidoptera: Pyralidae). Bul. HPT. 10: 1-7.

SAS Institute. 1990. SAS/STAT User's Guide, Version 6. Fourth Edition, Volume 2. SAS Institute Inc., North Carolina.

Schmutterer H. 1997. Side-effects of neem (Azadirachta indica) products on insect pathogens and natural enemies of spider mites and insects. J. Appl. Entomol. 121:121-128.

Steel R.G.D. \& J.H. Torrie. 1993. Prinsip dan Prosedur Statistika Suatu Pendekatan Biometrika. Sumantri B, Alih bahasa. PT Gramedia Pustaka Utama, Jakarta. 
Syahputra, E. 2005. Bioaktivitas Insektisida Botani Calophyllum soulattri Burm.f. (Clusiaceae) sebagai Pengendali Hama Alternatif [disertasi]. Institut Pertanian Bogor, Sekolah Pascasarjana, Bogor.

Syahputra, E., D. Prijono, Dadang, S. Manuwoto \& L.K. Darusman. 2006. Respons fisiologi larva Crocidolomia pavonana (F.) (Lepidoptera: Pyralidae) terhadap sediaan fraksi aktif kulit batang Calophyllum soulattri Burm. f. (Clusiaceae). Hayati. 13(1):712.

Syahputra, E., D. Prijono, S. Manuwoto, L.K. Darusman \& Dadang. 2004a. Aktivitas insektisida ekstrak kulit batang empat famili tumbuhan terhadap ulat krop kubis Crocidolomia pavonana (F.) J. Perlin. Tan. Indon. 10(1):13-22.
Syahputra, E., F. Rianto \& D. Prijono. 2001. Aktivitas insektisida ekstrak tumbuhan asal Kalimantan Barat terhadap kumbang kacang Callosobruchus maculatus (F.) dan ulat kubis Crocidolomia binotalis Zeller. J. Ilmu Pert. Indon. 10(1):8-13.

Syahputra, E., S. Manuwoto, L.K. Darusman, Dadang \& D. Prijono. 2004b. Aktivitas insektisida bagian tumbuhan Calophyllum soulattri Burm. f. (Clusiaceae) terhadap larva Lepidoptera. JHPT Trop. 4(1):23-31. 